\title{
Knowledge Base of Project Managers in THE SOUTH AFRICAN ICT SECTOR
}

\author{
Robert T. Hans ${ }^{1}$ and Pantaleo M.D. Rwelamila ${ }^{2}$ \\ ${ }^{1}$ Tshwane University of Technology, Pretoria, South Africa \\ hansretut.ac.za \\ ${ }^{2}$ Graduate School of Business Leadership, University of South Africa, Midrand, \\ South Africa \\ rwelapmdeunisa.ac.za
}

\begin{abstract}
The primary purpose of this research study is two-fold: Firstly, to establish the knowledge base of project managers in the South African ICT Sector. Secondly, to establish whether project management as a discipline is regarded as an important profession in the South African ICT Sector. The paper based on a questionnaire analyses and discusses the knowledge base of project managers of ICT organisations listed on the Johannesburg Securities Exchange (JSE) as well as the perceived importance of project management in the South African ICT Sector. The project managers lack some project management knowledge base in some of the nine categories of competencies. This confirms some of the findings by Rwelamila (2007) that project management training programmes offered by institutions of higher learning in South Africa are skewed. This paper also established that the organisations in the South African ICT Sector recognise project management as an important profession. The lack of some project management fundamental knowledge base by project managers necessitate that the organisations concerned should implement some of the following: review project management training programmes and implement mentoring and coaching programmes. This article reveals the knowledge base gaps of project managers in the South African ICT Sector. It also reveals whether project management is regarded as an important profession by organisations in the South African ICT Sector. It complements another research study done by Rwelamila (2007) in South Africa. It is directed to the South African organisations in the ICT Sector as well as institutions of higher learning in South Africa that offer project management training programmes.
\end{abstract}

\section{KEYWORDS}

Knowledge base, project managers, project management, expertise, competencies.

\section{INTRODUCTION}

Anderson and Merna (2005) state that projects that perform poorly signal a credibility gap as to the need for and competence of management in project mode. Provided that projects are led by knowledgeable and competent project managers, good project management techniques and tools alone are of little value to an organisation. After all, projects are managed by project managers. Natarajan Meghanathan, et al. (Eds): ITCS, SIP, JSE-2012, CS \& IT 04, pp. 455-478, 2012.

(c) CS \& IT-CSCP 2012

DOI : $10.5121 /$ csit.2012.2141 
Project success requires both project management competence and organisational project maturity and capability (Gehring, 2007). Institutions of higher learning in South Africa play a critical role in providing project management competence to project managers. However, according to Rwelamila (2007), the project management training programmes offered by the institutions of higher learning in South Africa are skewed - most of the programme courses are dominated by 'technical knowledge base' and very little of 'social-cultural knowledge base'.

The important role played by a project manager in ensuring project success, as well as the findings by Rwelamila (2007), provide a compelling reason for focusing on project managers in terms of who gets selected to be a project manager and also in determining the knowledge base of these project managers in the South African ICT Sector. The latter statement serves as the research problem for this study.

\section{RESEARCH QUESTIONS}

The following are the two primary research questions of this research study:

- What is the knowledge base of project managers in the South African ICT sector?

- Is project management recognised as an important profession in the South African ICT Sector?

The secondary question that this study seeks to address is based on the first primary question of this study and it is:

- What should be done to address issues of South African ICT project managers' competencies in project management?

Now that the research questions have been outlined, the next section seeks to review what the literature states with regard to the knowledge base of project managers.

\section{KNOWLEDGE BASE OF PROJECT MANAGERS IN THE ICT SECTOR: THEORY AND PRACTICE}

Project management is becoming an increasingly important discipline of management in all companies around the world (Graham and Englund, 2004). Since organisations use project management to enable them to manage projects better, the spotlight has fallen on project managers, who play an important role in making projects successful. Leung (2002) identifies the need to have a software project manager as a number one common good management practice. Furthermore, Day and Bobeva (2003) state that project managers have great influence on the success of IT projects. Ceran and Dorman (1995) concur with this view and state that successful project management systems and competent project managers form the foundation for successful projects. The popularity of project management and the increased demand for project managers has seen an increased interest in the competence of project managers (Crawford and Pollack, 2007). Therefore the selection process of a competent project manager is a necessary one. After all, projects are managed by project managers.

Project failures have become a common thing, both nationally and internationally. Standish Group (2004) state that almost 20 percent of Information and Technology (IT) projects are abandoned before they are completed and less than a third are completed within time and budget. 
Project management knowledge base and skills possessed by project managers should aid in deterring the project failure rate and thereby reversing the misfortunes.

From this discussion it is clear that a project manager plays a critical role in ensuring project success. It is therefore important that the focus should be on project managers in terms of who gets selected to be a project manager in the ICT Sector.

\subsection{Who gets appointed as project managers in the ICT Sector?}

A project manager is the single point of responsibility for all key decisions of the project. Furthermore, Dvir, Sadeh \& Malach-Pines (2006), purport that better fit between project managers and the projects assigned to them has a positive contribution to project success. The assertion is also further supported by Burke (2003), who states:

"Experience has shown that the selection of the project manager is a key appointment which can influence the success or failure of the project."

Graham and Englund (2004) refer to project managers that are tasked to manage projects, without the necessary project management knowledge base and skills and support systems such as project manager development programmes, as 'accidental' project managers. Gehring (2007) states that instead of carefully selecting competent project managers, organisations tend to create 'accident' project managers by simply promoting a good technician or administrator into a project leadership role. This assertion is also supported by Nelloreisher and Blanchandra (2001) who state that often a project manager is given a project leadership position without the required knowledge base and skills. Furthermore, technical expertise is not an overriding indicator of the effective project manager and the appointment of best technical employees as project managers purely on the basis of their technical knowledge base and respective skills does not make sense (Rwelamila, 2007). Organisations need to understand that the knowledge base and skill set for project management is different from that of other professional disciplines (Graham and Englund, 2004). 'Accidental' project managers or project managers who have no organisational support, cannot apply solid leadership and communication skills, and should not be expected to manage projects successfully (Kappelman, McKeeman \& Zhang, 2007).

According to Rwelamila (2007) there are six (6) competencies that an outstanding project manager should possess. These are: Sense of ownership and mission, Political awareness, Relationship development, Strategic influence, Interpersonal assessment and Action orientation. On the other hand, Gehring (2007) states that a project manager needs the following six (6) units of competencies: achievement and action, helping and human service, impact and influence, managerial, cognitive as well as personal effectiveness. One can clearly see that the competencies mentioned by both Rwelamila (2007) and Gehring (2007) are somewhat similar. According to Kimmons (1989) a project manager should possess the following qualities: Leadership qualities with organisational ability, Experience in project management, Co-ordination ability, Ability to encourage team members, Sensitivity to human relations, Complete understanding of procedures of his/her company and Ability to maintain a healthy relationship with the client.

A study by Brill, Bishop \& Walker (2006) found that problem-solving expertise and leadership expertise were ranked as the top two key competencies required by a project manager. Weirauch (2000) echoes these sentiments and states that a project manager should be competent in two primary knowledge base sets - technical knowledge base and leadership knowledge base. 
Marken (1998) also agrees with this and states that both technical and business knowledge bases are needed by a project manager. According to Taylor (2006), a project manager needs two classes of skills: technical and human or relational skills. Furthermore, Thite (1999) states that project managers of successful IT projects have transformational and technical leadership qualities to a greater extent than managers of less successful projects. These views are also supported by Muzio, Fisher, Thomas \& Peters (2007), who indicate that transformational leadership is important to project management.

Schmid and Adams (2008) advocate that a project manager should have, amongst other things, participative leadership style and an ability to motivate team members. Pheng and Lee (1997) state that each project's phase demands different skills from the project manager. Moreover, Pheng and Lee (1997) state that a project manager should have the following skills (criteria): leadership, decision-making, stability, good listening and information-gathering skills, good analytical abilities, flexibility, multi-disciplinary oriented, right temperament, planning, management and follow-up skills. Dainty, Cheng \& Moore (2005) also have a similar list of skills that a competent project manager is expected to possess. Skulmoski (2000), on the other hand, states that competencies are varied, multi-dimensional and are much broader than skills and knowledge. Competencies (soft competencies) include traits, motives, self-image and social role, while hard competencies refer to skills and knowledge (Skulmoski, 2000).

As long as project managers are sent to 'war' without any necessary 'armour', the high failure rate of ICT projects will remain with us for some time. A statement by Carbone and Gholston (2004:16) sums it up:

"We would not expect an untrained ear to lead a symphony; why do we expect project managers to deliver successful projects without investing in their development skills?"

A study by Boyle and Strong (2006) established that amongst a list of key skills that organisations expect from recent graduates of university programmes are team skills and knowledge (which includes project leadership capabilities). Mann (2002) states that the skills gap has a negative contribution on the failure rate of information systems. A South African report on Joint Initiative on Priority Skills Acquisition (JIPSA) (2007) supports this assertion and states that the lack of project management capability has a negative impact on service delivery. This reemphasises the importance of learning institutions aligning their curricula offerings with organisational needs. This re-alignment of curricula by institution of higher learning is also emphasised by Rwelamila (2007), whose study established that programmes aimed at equipping project managers in the South African industry fall short of what is required/expected. Based on these findings, Rwelamila (2007) advocates for re-alignment of these programmes and further suggests an appropriate construction project management (CPM) programme framework.

Following the above discussion, Table 1 below provides a summary of competencies expected from a competent project manager. Similar/identical competencies by different authors have been grouped together for the sake of conciseness. As can be seen from Table 1, most of the authors seem to be in agreement on the importance of having a project manager with multidisciplinary orientation which includes leadership, management and technical skills. Again, many authors indicate the importance of personal characteristics such as analytical ability, flexibility, good listening skills, good communication and effective problem-solving. 


\begin{tabular}{|c|c|c|c|c|c|c|c|}
\hline Rwelamila (2007) & Gehring (2007) & $\begin{array}{l}\text { Brill, Bishop \& } \\
\text { Walker (2006) }\end{array}$ & $\begin{array}{c}\text { Weirauch (2000); } \\
\text { Marken (1998) }\end{array}$ & $\begin{array}{c}\text { Thite (1999) *; } \\
\text { Murio, Fisher, Thomas \& } \\
\text { Peters (2007) **; } \\
\text { Murio, Fisher, Thomas \& } \\
\text { Peters (2007) *; } \\
\text { Schmid and Adams (2008)* }\end{array}$ & Kimmons (1989) & $\begin{array}{c}\text { Pheng and Lee } \\
(1997) ; \\
\text { Dainty, Cheng \& } \\
\text { Moore (2005) }\end{array}$ & Skulmoski (2000) \\
\hline $\begin{array}{l}\text { - Sense of } \\
\text { ownership and } \\
\text { mission } \\
\text { - Political } \\
\text { awareness } \\
\text { - Relationship } \\
\text { - development } \\
\text { - Strategic } \\
\text { influence } \\
\text { - Interpersonal } \\
\text { assessment } \\
\text { - Action } \\
\text { orientation }\end{array}$ & $\begin{array}{l}\text { - Achievement } \\
\text { and action } \\
\text { - Helping and } \\
\text { human service } \\
\text { - Impact and } \\
\text { influence } \\
\text { - Managerial } \\
\text { - Cognitive } \\
\text { - Personal } \\
\text { effectiveness }\end{array}$ & $\begin{array}{l}\text { - Problem- } \\
\text { solving } \\
\text { expertise } \\
\text { - Leadership } \\
\text { expertise }\end{array}$ & $\begin{array}{l}\text { - Technical skills } \\
\text { - Leadership } \\
\text { skills. } \\
\text { - Business skills }\end{array}$ & $\begin{array}{l}\text { - Transformational } \\
\text { leadership qualities * } \\
\text { - Technical } \\
\text { leadership } \\
\text { qualities } \\
\text { - Participative leadership } \\
\text { style ** } \\
\text { - Ability to motivate team } \\
\text { members *ै }\end{array}$ & $\begin{array}{l}\text { - Leadership qualities } \\
\text { with organisational } \\
\text { ability. } \\
\text { - Experience in project } \\
\text { management. } \\
\text { - Coordination ability. } \\
\text { - Ability to encourage } \\
\text { - } \text { team members. } \\
\text { - } \text { rensitivity to human } \\
\text { - Complete } \\
\text { understanding of } \\
\text { procedures of hisher } \\
\text { company. } \\
\text { - Ability to maintain a } \\
\text { healthy relationship } \\
\text { with the client. }\end{array}$ & $\begin{array}{l}\text { - Leadership } \\
\text { - Decision-making } \\
\text { - Stability } \\
\text { - Good listening } \\
\text { and information } \\
\text { gathering skills } \\
\text { - Good analytical } \\
\text { abilities } \\
\text { - Flexibility } \\
\text { - Multi-disciplinary } \\
\text { oriented } \\
\text { - Right } \\
\text { temperament } \\
\text { - Planning } \\
\text { - Management and } \\
\text { follow-up skills. }\end{array}$ & 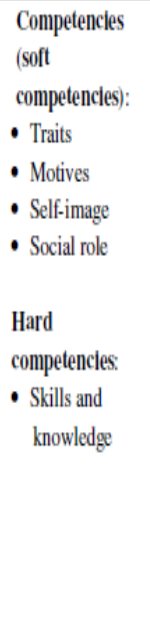 \\
\hline
\end{tabular}

Note: The asterisk (s) (* or **) indicate which competencies are cited by which author(s).

Based on the discussion above, the following hypothesis is made for this research study:

$H_{1}$ : Project managers in the South African ICT Sector possess correct project management and leadership skills to mange projects.

A competent project manager alone cannot guarantee project success; a mature project management organisation is necessary, too (Gehring, 2007). That is, ICT organisations must value project management skills and project management itself as an important discipline. This therefore brings us to another important question to which this study seeks to establish answers. The question relates to the importance of project management in the South African ICT sector. The next section will look at how project management is viewed by the ICT Sector globally.

\section{The Importance Of Project Management in the ICT Sector}

According to Geist and Myers (2007), project management is a critical success factor of organisational change in any industry. Tesch, Kloppenborg \& Frolick (2007) state:

"Effective project management (PM) is vital to the success of any software development project. In fact, the management aspects of a project are typically more critical to its success than the technical aspects."

Huff and Prybutok (2008) concur with Geist and Myers (2007) and state that project management plays a vital role in production and innovation in today's society. The importance of project 
management in the ICT sector is also confirmed by the study done by Kim, Hsu \& Stern (2006), which indicates that information systems (IS) and IS industry professionals value project management. Moreover, many organisations realise the importance of project management in helping them to handle complex projects (Schwalbe, 2007). Another reason that has elevated the status of project management is the strategic role that IT plays in many organisations (Tesch, Kloppenborg, \& Frolick, 2007).

The importance of project management has further been brought to bear by a number of organisations that have become 'project-based' (Brewer, 2005). Project management enables project managers to use a systems approach in understanding how projects relate to each other and to the organisation as a whole. Schwalbe (2007) further states that this systematic way of thinking has an important effect on the way projects are selected and also in the management of projects. The results of research by Standing et al. (2006) further indicate the importance of project management by placing poor project management as one of the top five reasons why IT projects fail. This is confirmed by Schimmoller (2001) who states:

\section{"The costs of poor project management can be tremendous."}

The lack of project management capacity has been attributed as one of the most common reasons for poor service delivery by the South African government (JIPSA, 2007). McCormick (2006) further states that managers ought to treat project management with same respect as business improvement and change management, and should be seen as a core competency for competitive advantage in a business environment. This assertion is supported by Gillingham (2006), who reported that there is a growing body of evidence that capability in managing projects leads to superior performance in implementation strategy.

Based on the discussion above, the following hypothesis is made for this research study:

$\mathrm{H}_{2}$ : Project management is recognised as an important profession in the South African ICT Sector.

The above discussion has provided a global view on who gets appointed as a project manager and what skills and knowledge they should possess. Also, the discussion has given an overview of the importance of project management as a profession and the general performance levels of ICT projects. It would therefore be informative to establish how the above discussion relates to the South African context.

\section{RESEARCH METHODOLOGY}

This research study is more structured and more controlled in terms of the measuring instrument used and therefore lends itself to the quantitative research approach (Neser, Joubert \& Sonnekus, 1995).

\section{SAMPLE DeSign AND SAMPLE Size}

The population of interest for this study is limited to all project managers of all ICT organisations listed on the Johannesburg Securities Exchange (JSE). The other reason for using ICT organisations on the JSE is the availability of the list of these listed companies, as well as the supposed expectations that project managers working for these companies are expected to possess 
the necessary skills to be successful in their roles as project managers. Since the sample frame is readily available (list of ICT organisations listed on the JSE), unrestricted simple random element selection was used as a sampling design.

During the time of this study there were nineteen (19) ICT organisations that were listed on the JSE. Sixteen (16) organisations were randomly selected as explained above, as a sample for this study. Four (4) companies either declined to participate or mentioned that they did not have any ICT projects and therefore had no project managers in their employment ranks. Therefore, twelve (12) organisations (75\%) of the sixteen (16) selected organisations participated in this study. The twelve (12) organisations had forty-five (45) project managers amongst themselves. Twenty six (26) $(58 \%)$ project managers successfully participated in this study.

\section{DATA COLLECTION METHOD}

Data was collected using an internet-hosted, multi-part questionnaire which had three sections made up of one hundred and twenty eight (128) questions. The questionnaire was placed on a website for participating project managers to complete. Each participating project manager was given a unique username and password to use for logging in, as well as to ensure data confidentiality. Telephone calls were made to participating project managers in order to ensure a high response rate to the questionnaire.

The three sections that made up the questionnaire were: Section A - Demographic data, Section B - Skills and competencies of project manager, Section C - Perceived importance of project management in the South African ICT sector. Brill, Bishop \& Walker (2006) identify one hundred and seventeen (117) competencies and characteristics organised under nine categories, namely, Problem-Solving Expertise, Leadership Expertise, Context Knowledge, Analytical Expertise, People Expertise, Communication Expertise, Personal Characteristics, Project Administration Expertise and Tools Expertise that an effective project manager should possess. Section B of the questionnaire uses these competencies and asks project managers to rank their level of skills for each of the competencies and characteristics. The questions in Section B used a Likert 4-point rating scale (4 - highly skilled and 1 - poorly skilled) and participants were requested to rate their level of competencies or expertise by choosing any of the rating scales.

\section{Method FOR ANALYSIS}

In analysing the data, statistical non-parametric methods such as chi-square were used to test the hypotheses. Non-parametric methods were chosen, as the data measurement scale used in this study is nominal (classificatory). The two hypotheses of this study were tested using the one sample Z-test for proportions (Diamantopolous and Schlegelmilch, 1997). In the one sample Ztest, it is appropriate to state an arbitrary value against which the hypothesis is tested. For the purpose of this study, the hypothesised proportion that was used for both hypotheses was $66.7 \%$ (significantly more than two-thirds of the population). For the first hypothesis of this study, proportions were calculated by summing up the proportions of respondents who indicated either "skilled" or "highly-skilled" as an answer to each question of the nine categories, whilst for the second hypothesis the proportions were calculated by summing up the proportions of respondents who provided "Yes" as an answer to each question of Section C of the research questionnaire. A test of significance was made to each question of Sections B and C in the research questionnaire 
to establish whether the hypotheses should be rejected or accepted. The statistic analytical software (SAS) version 9.1 and SPSS version 14.0 were used as tools for analysis.

\section{SYNTHESIS AND ANALYSIS OF RESULTS}

\subsection{Demographic Profile of Respondents}

The demographic profile of the respondents shows that the respondents were mostly male $(61.5 \%)$ and white $(53.8 \%)$. This should not be surprising, given the employment history of South Africa. The project management experience profile of the respondents indicates that most respondents $(46.2 \%)$ have relatively less experience ( 1 - 5 years) in project management, while only $19.2 \%$ of respondents have $11-20$ years of experience in project management. It is therefore clear that that the majority of respondents are less experienced project managers and it further indicates that the majority of projects are managed by project managers who are relatively less experienced in project management. On the other hand, the majority of the respondents $(92.3 \%)$ have received formal training in project management. This is a sign that organisations realise the need for providing proper training and support systems for project managers and are therefore moving away from having projects that are managed by 'accidental project managers'.

\subsection{Knowledge Base of the Respondents}

In this section, the first hypothesis in this study will be tested. The test results of the hypothesis tests enable us to analyse skills competencies of the respondents. Therefore, an analysis of the respondents' skills competencies will also be performed whilst analysing the test results of the hypothesis tests.

\subsubsection{Testing of hypothesis 1}

The first hypothesis in this research study states that:

"Project managers in the South African ICT sector perceive themselves to have sufficient project management and leadership skills to manage projects."

This hypothesis was tested using the one sample Z-test for proportions (Diamantopolous and Schlegelmilch, 1997). In the one sample Z-test, it is appropriate to state an arbitrary value against which the hypothesis is tested. For the purpose of this study, the hypothesised proportion that was used was $66.7 \%$, with the idea that we are interested in knowing which specific skills were perceived to be well developed by significantly more than two-thirds of the population. The proportions were calculated by summing up the proportions of respondents who indicated either "skilled" or "highly-skilled" as an answer to each question of the nine categories.

To establish which specific skills were perceived to be well developed by significantly more than two-thirds in the population, the following hypotheses were formulated:

$\mathrm{H}_{0}$ : The percentage of respondents who chose either skilled or highly-skilled as an answer is less than or equal to $66.7 \%$; against

$\mathrm{H}_{1}$ : More than $67 \%$ of the respondents chose either skilled or highly-skilled as an answer. 
For each category of skills of competencies, a test of significance was made to establish which skills were perceived to be well-developed by significantly more than two-thirds in the population.

\subsubsection{Test of significance for problem-solving expertise}

Table 2 presents the results of the Z-tests of each question in Category 1 (see Appendix A - The Primary Research Instrument), and indicates that in four of the nine skills listed in the ProblemSolving expertise category, significantly ( $\mathrm{p}$-value $=\alpha<0.001$ ) more than two-thirds (or $66.7 \%$ ) of the respondents felt they were appropriately skilled. For one of the skills, namely skills to frame a problem, at $\alpha=0.01$, the respondents felt satisfied with their skills levels. Skills to plan contingencies were only significant at $\alpha=0.03$. Therefore, the skills in which the respondents thought they were most lacking were skills to manage crises, skills to manage risk as well as skills to assess risk (these were all significant at $\alpha=0.11$ ). Based on the discussion above, the null hypothesis is rejected for six skills of competencies (where $p>=81 \%$ - these are skills that were perceived to be highly-developed by the participants) and failed to be rejected for the other three skills of competencies (where $\mathrm{p}=77 \%$ - these are skills that were perceived to be lacking by the participants).

Table 2 Test of significance for problem-solving expertise

\begin{tabular}{|l|c|c|l|l|}
\hline Problem solving expertise & P & Z & P-value & Significance \\
\hline Skills to conduct business ethically & 0.885 & 3.47 & 0.0003 & $* * *$ \\
\hline Skills to recognize a problem & 0.962 & 7.81 & 0.0000 & $* * *$ \\
\hline Skills to manage crises & 0.769 & 1.24 & 0.1080 & \\
\hline Skills to manage risk & 0.769 & 1.24 & 0.1080 & \\
\hline Skills to frame a problem & 0.846 & 2.53 & 0.0057 & $* *$ \\
\hline Skills to assess risk & 0.769 & 1.24 & 0.1080 & \\
\hline Skills to plan contingencies & 0.808 & 1.82 & 0.0344 & $*$ \\
\hline Skills to know the escalation point & 0.923 & 4.90 & 0.0000 & $* * *$ \\
\hline Skills to understand and apply alternative methods & 0.885 & 3.47 & 0.0003 & $* * *$ \\
\hline
\end{tabular}

*** Highly significant; ** More Significant; * Significant; (blank) Not significant

\subsubsection{Test of significance for leadership expertise}

Table 2 presents the results of the Z-tests of each question in Category 2 (see Appendix A - The Primary Research Instrument), and shows that for three of the sixteen skills listed in the Leadership Expertise category, significantly ( $\mathrm{p}$-value $=\alpha<0.001$ ) more than two-thirds (or $66.7 \%$ ) of the respondents felt they were appropriately skilled. For nine of the skills, the respondents felt satisfied with their skills levels (at $\alpha=0.01$ ). Therefore, the skills in which the respondents thought they were most lacking were expertise to make time-sensitive decisions effectively, negotiate effectively, be persuasive as well as skills to coach, mentor or teach (their significance at $\alpha>=0.11$ ). Therefore, based on the discussion above, the null hypothesis is rejected for six skills of competencies (where $\mathrm{p}>=85 \%$ - these are skills that were perceived to 
be highly developed by the participants) and failed to be rejected for the other three skills of competencies (where $\mathrm{p}=77 \%$ - these are skills that were perceived to be lacking by the participants).

Table 2 Test of significance for leadership expertise

\begin{tabular}{|l|c|c|l|l|}
\hline Leadership expertise & $\mathbf{p}$ & $\mathbf{Z}$ & $\mathbf{P}$-value & Significance \\
\hline Expertise to share credit for successes & 0.846 & 2.53 & 0.0057 & $* *$ \\
\hline $\begin{array}{l}\text { Expertise to make time-sensitive decisions } \\
\text { effectively }\end{array}$ & 0.769 & 1.24 & 0.1080 & \\
\hline Expertise to delegate and follow up effectively & 0.846 & 2.53 & 0.0057 & $* *$ \\
\hline Expertise to develop and execute a project plan & 0.885 & 3.47 & 0.0003 & $* * *$ \\
\hline Expertise to take responsibility for failures & 0.846 & 2.53 & 0.0057 & $* *$ \\
\hline Expertise to align or focus team members & 0.846 & 2.53 & 0.0057 & $* *$ \\
\hline $\begin{array}{l}\text { Expertise to know when to take control and when to } \\
\text { back off }\end{array}$ & 0.846 & 2.53 & 0.0057 & $* *$ \\
\hline Expertise to motivate team members & 0.846 & 2.53 & 0.0057 & $* *$ \\
\hline Expertise to promote teamwork & 0.846 & 2.53 & 0.0057 & $* *$ \\
\hline Expertise to lead and facilitate a meeting & 0.885 & 3.47 & 0.0003 & $* * *$ \\
\hline Expertise to manage group dynamics & 0.846 & 2.53 & 0.0057 & $* *$ \\
\hline Expertise to be diplomatic & 0.846 & 2.53 & 0.0057 & $* *$ \\
\hline Expertise to negotiate effectively & 0.731 & 0.73 & 0.2318 & \\
\hline Expertise to be persuasive & 0.769 & 1.24 & 0.1080 & \\
\hline Expertise to coach, mentor or teach & 0.731 & 0.73 & 0.2318 & \\
\hline Expertise to build esteem to others & 0.885 & 3.47 & 0.0003 & $* * *$ \\
\hline
\end{tabular}

*** Highly significant; ** More Significant; * Significant; (blank) Not significant

\subsubsection{Test of significance for context knowledge}

Table 3 presents the results of the Z-tests of each question in Category 3 (see Appendix A - The Primary Research Instrument), and shows that for eleven of the eighteen context knowledge areas listed in the Context Knowledge category, significantly ( $\mathrm{p}$-value $=\alpha<0.001$ ) more than twothirds (or 66.7\%) of the respondents felt they had appropriate knowledge. For two context knowledge areas, namely, 'know the team members' and 'understand the workflow of the organisation', the respondents felt satisfied with their context knowledge levels (at $\alpha=0.01$ ). The context knowledge area, 'knowledge of available resources' was only significant at $\alpha=0.03$. The respondents thought they were lacking in the following four context knowledge areas: knowledge of client, knowledge of vendors, knowledge of politics or culture outside the organisation and understanding the decision-making process outside the organisation. Therefore, based on the discussion above, the null hypothesis is rejected for fourteen skills of competencies (where $\mathrm{p}>=81 \%$ - these are context knowledge areas that were perceived to be highly developed by the participants) and failed to be rejected for the other three skills of competencies (where $\mathrm{p}$ $<=77 \%$ - these are context knowledge areas that were perceived to be lacking by the participants). 
Table 3 Test of significance for context knowledge

\begin{tabular}{|l|c|c|l|l|}
\hline Context knowledge & $\mathbf{p}$ & \multicolumn{1}{|c|}{$\mathbf{Z}$} & \multicolumn{1}{|c|}{ P-value } & Significance \\
\hline Know the goals of the project & 1.000 & $\mathrm{Nc}$ & & $* * *$ \\
\hline Know the scope of the project & 0.923 & 4.90 & 0.0000 & $* * *$ \\
\hline Know the mission of the project & 0.962 & 7.81 & 0.0000 & $* * *$ \\
\hline Know how project success is measured & 0.962 & 7.81 & 0.0000 & $* * *$ \\
\hline Know the available resources & 0.808 & 1.82 & 0.0344 & $*$ \\
\hline Know oneself & 1.000 & $\mathrm{Nc}$ & & $* * *$ \\
\hline Know the team members & 0.846 & 2.53 & 0.0057 & $* *$ \\
\hline $\begin{array}{l}\text { Understand the decision making process within the } \\
\text { organisation }\end{array}$ & 0.885 & 3.47 & 0.0003 & $* * *$ \\
\hline Know the client & 0.769 & 1.24 & 0.1080 & \\
\hline Know the goals of the organisation & 0.962 & 7.81 & 0.0000 & $* * *$ \\
\hline Know the politics or culture within the organisation & 0.923 & 4.90 & 0.0000 & $* * *$ \\
\hline Understand the workflow of the organisation & 0.846 & 2.53 & 0.0057 & $* *$ \\
\hline Know the mission of the organization & 1.000 & $\mathrm{Nc}$ & & $* * *$ \\
\hline Understand the industry in which one works & 0.962 & 7.81 & 0.0000 & $* * *$ \\
\hline Know the vendors & 0.731 & 0.73 & 0.2318 & \\
\hline Know the politics or culture outside the organisation & 0.731 & 0.73 & 0.2318 & \\
\hline Understand the fields related to the project & 0.923 & 4.90 & 0.0000 & $* * *$ \\
\hline $\begin{array}{l}\text { Understand the decision-making process outside the } \\
\text { organisation }\end{array}$ & 0.769 & 1.24 & 0.1080 & \\
\hline
\end{tabular}

*** Highly significant; ** More Significant; * Significant; (blank) Not significant

\subsubsection{Testing of significance for analytical expertise}

Table 4 presents the results of the Z-tests of each question in Category 4 (see Appendix A - The Primary Research Instrument), and indicates that for one of the four skills listed in the Analytical Expertise category, significantly ( $\mathrm{p}$-value $=\alpha<0.001$ ) more than two-thirds (or 66.7\%) of the respondents felt they were appropriately skilled. For two of the skills, the respondents felt satisfied with their skills levels (at $\alpha=0.01$ ). Expertise to do research was only significant at $\alpha=$ 0.03. Therefore, there was no expertise which respondents thought they were most lacking in for the Analytical Expertise category. Therefore, the null hypothesis is rejected for all of the four skills of competencies (where $\mathrm{p}>=81 \%$ - these are skills that were perceived to be highly developed by the participants). 
Table 4 Test of significance for analytical expertise

\begin{tabular}{|l|c|c|c|l|}
\hline Analytical expertise & $\mathbf{P}$ & $\mathbf{Z}$ & P-value & Significance \\
\hline Expertise to prioritize & 0.846 & 2.53 & 0.0057 & $* *$ \\
\hline Expertise to capture and use knowledge & 0.923 & 4.90 & 0.0000 & $* * *$ \\
\hline Expertise to do research & 0.808 & 1.82 & 0.0344 & $*$ \\
\hline $\begin{array}{l}\text { Expertise to use project management } \\
\text { methodologies }\end{array}$ & 0.846 & 2.53 & 0.0057 & $* *$ \\
\hline
\end{tabular}

*** Highly significant; ** More Significant; * Significant; (blank) Not significant

\subsubsection{Test of significance for people expertise}

Table 5 presents the results of the Z-tests of each question in Category 5 (see Appendix A - The Primary Research Instrument), and shows that for only one of the seven skills listed in the People Expertise category, significantly ( $\mathrm{p}$-value $=\alpha=0.0003<0.001$ ) more than two-thirds (or $66.7 \%$ ) of the respondents felt they were appropriately skilled. Again, in only one of the seven skills did the respondents feel satisfied with their skills levels (at $\alpha=0.01$ ). The expertise to manage expectations was only significant at $\alpha=0.03$. Therefore, there were four skills in which the respondents thought they were most lacking, namely, expertise to resolve conflict, expertise to understand human nature, expertise to understand and overcome resistance to change, as well as expertise to manage stress, self and others. Therefore, based on the discussion above, the null hypothesis is rejected for three skills of competencies (where $p>=81 \%$ - these are skills that were perceived to be highly developed by the participants) and failed to be rejected for the other four skills of competencies (where $\mathrm{p}<=77 \%$ - These are skills that were perceived to be lacking by the participants).

Table 5 Test of significance for people expertise

\begin{tabular}{|l|c|c|c|l|}
\hline People expertise & $\mathbf{P}$ & $\mathbf{Z}$ & P-value & Significance \\
\hline Expertise to manage expectations & 0.808 & 1.82 & 0.0344 & $*$ \\
\hline Expertise to resolve conflict & 0.769 & 1.24 & 0.1080 & \\
\hline Expertise to understand human nature & 0.769 & 1.24 & 0.1080 & \\
\hline $\begin{array}{l}\text { Expertise to understand and overcome } \\
\text { resistance to change }\end{array}$ & 0.577 & 0.93 & 0.8237 & \\
\hline Expertise to help others achieve their goals & 0.846 & 2.53 & 0.0057 & $* *$ \\
\hline Expertise to manage stress, self and others & 0.769 & 1.24 & 0.1080 & \\
\hline Expertise to build consensus & 0.885 & 3.47 & 0.0003 & $* * *$ \\
\hline
\end{tabular}

*** Highly significant; ** More Significant; * Significant; (blank) Not significant 


\subsubsection{Test of significance for communication expertise}

Table 6 presents the results of the Z-tests of each question in Category 6 (see Appendix A - The Primary Research Instrument), and shows that for five of the eight skills listed in the Communication Expertise category, significantly ( $\mathrm{p}$-value $=\alpha<=0.0003<0.001$ ) more than two-thirds (or 66.7\%) of the respondents felt they were appropriately skilled. In only one of the eight skills, namely, the expertise to present effectively, the respondents felt comfortable and it was only significant at $\alpha=0.03$. Therefore, there were two skills in which the respondents thought they were most lacking, namely, expertise to network effectively and expertise to effectively communicate graphical information. Therefore, based on the discussion above, the null hypothesis is rejected for five skills of competencies (where $\mathrm{p}>=81 \%$ - these are skills that were perceived to be highly developed by the participants) and failed to be rejected for the other four skills of competencies (where $\mathrm{p}=77 \%$ - these are skills that were perceived to be lacking by the participants).

Table 6 Test of Significance for communication expertise

\begin{tabular}{|l|c|c|c|l|}
\hline Communication expertise & $\mathbf{p}$ & $\mathbf{Z}$ & P-value & Significance \\
\hline Expertise to listen effectively & 0.923 & 4.90 & 0.0000 & $* * *$ \\
\hline Expertise to effectively communicate verbally & 0.885 & 3.47 & 0.0003 & $* * *$ \\
\hline Expertise to effectively communicate in writing & 0.923 & 4.90 & 0.0000 & $* * *$ \\
\hline Expertise to deliver good and bad news effectively & 0.885 & 3.47 & 0.0003 & $* * *$ \\
\hline Expertise to present effectively & 0.808 & 1.82 & 0.0344 & $*$ \\
\hline Expertise to liaise among stakeholders & 0.923 & 4.90 & 0.0000 & $* * *$ \\
\hline Expertise to network effectively & 0.769 & 1.24 & 0.1080 & \\
\hline $\begin{array}{l}\text { Expertise to effectively communicate graphical } \\
\text { information }\end{array}$ & 0.769 & 1.24 & 0.1080 & \\
\hline
\end{tabular}

*** Highly significant; ** More Significant; * Significant; (blank) Not significant

\subsubsection{Test of significance for personal characteristics}

Table 7 presents the results of the Z-tests of each question in Category 7 (see Appendix A - The Primary Research Instrument), and shows that thirty-seven of the thirty-eight personal characteristics listed in the Personal Characteristics category, significantly ( $\mathrm{p}$-value $=\alpha<0.001$ ) more than two-thirds (or 66.7\%) of the respondents felt they strongly identified with. The remaining personal characteristic, namely, 'I have a sense of humour', the respondents felt they satisfactorily identify with. Therefore, there were no personal characteristics in which respondents thought they were most lacking for this category. Therefore, the null hypothesis is rejected for all of the thirty-eight personal characteristics (where $\mathrm{p}>=85 \%$ - these are personal characteristics that were perceived to be highly developed by the participants). 
Table 7 Test of significance for personal characteristics

\begin{tabular}{|c|c|c|c|c|}
\hline Personal characteristics & $\mathbf{P}$ & $\mathbf{Z}$ & P-value & Significance \\
\hline I have integrity & 1.000 & $\mathrm{Nc}$ & & $* * *$ \\
\hline I am honest & 1.000 & $\mathrm{Nc}$ & & $* * *$ \\
\hline I am good under pressure & 0.962 & 7.81 & 0.0000 & $* * *$ \\
\hline I have common sense & 1.000 & $\mathrm{Nc}$ & & $* * *$ \\
\hline I am clear & 1.000 & $\mathrm{Nc}$ & & $* * *$ \\
\hline I am committed & 1.000 & $\mathrm{Nc}$ & & $* * *$ \\
\hline I am focused & 1.000 & $\mathrm{Nc}$ & & $* * *$ \\
\hline I am results-driven & 1.000 & $\mathrm{Nc}$ & & $* * *$ \\
\hline I am persistent & 1.000 & $\mathrm{Nc}$ & & $* * *$ \\
\hline I am flexible & 0.962 & 7.81 & 0.0000 & $* * *$ \\
\hline I have confidence & 1.000 & $\mathrm{Nc}$ & & $* * *$ \\
\hline I am proactive & 1.000 & $\mathrm{Nc}$ & & $* * *$ \\
\hline I am accessible or visible & 1.000 & $\mathrm{Nc}$ & & $* * *$ \\
\hline I am able to control my temper & 0.962 & 7.81 & 0.0000 & $* * *$ \\
\hline I am fair & 1.000 & $\mathrm{Nc}$ & & $* * *$ \\
\hline I have a positive attitude & 1.000 & $\mathrm{Nc}$ & & $* * *$ \\
\hline I am resilient & 0.923 & 4.90 & 0.0000 & $* * *$ \\
\hline I have a strong work ethic & 1.000 & $\mathrm{Nc}$ & & $* * *$ \\
\hline I am disciplined & 1.000 & $\mathrm{Nc}$ & & $* * *$ \\
\hline I am able to learn on the fly & 0.962 & 7.81 & 0.0000 & $* * *$ \\
\hline I pay attention to details & 1.000 & $\mathrm{Nc}$ & & $* * *$ \\
\hline I am a realist & 1.000 & $\mathrm{Nc}$ & & $* * *$ \\
\hline I am open & 1.000 & $\mathrm{Nc}$ & & $* * *$ \\
\hline I deal well with ambiguity & 0.923 & 4.90 & 0.0000 & $* * *$ \\
\hline I am logical & 1.000 & $\mathrm{Nc}$ & & $* * *$ \\
\hline I am reasonable & 1.000 & $\mathrm{Nc}$ & & $* * *$ \\
\hline I have a sense of urgency & 1.000 & $\mathrm{Nc}$ & & $* * *$ \\
\hline I am charismatic & 0.885 & 3.47 & 0.0003 & $* * *$ \\
\hline I have tact & 1.000 & $\mathrm{Nc}$ & & $* * *$ \\
\hline I am creative & 1.000 & $\mathrm{Nc}$ & & $* * *$ \\
\hline I have high energy & 0.962 & 7.81 & 0.0000 & $* * *$ \\
\hline I am innovative & 1.000 & $\mathrm{Nc}$ & & $* * *$ \\
\hline I have a sense of humor & 0.846 & 2.53 & 0.0057 & $* *$ \\
\hline
\end{tabular}




\begin{tabular}{|l|r|r|r|r|}
\hline I am courageous & 1.000 & $\mathrm{Nc}$ & & $* * *$ \\
\hline I am patient & 0.885 & 3.47 & 0.0003 & $* * *$ \\
\hline I am a visionary & 1.000 & $\mathrm{Nc}$ & & $* * *$ \\
\hline I have empathy & 1.000 & $\mathrm{Nc}$ & & $* * *$ \\
\hline $\begin{array}{l}\text { I have an outlet to keep work in } \\
\text { perspective }\end{array}$ & 0.962 & 7.81 & 0.0000 & $* * *$ \\
\hline
\end{tabular}

*** Highly significant; ** More Significant; * Significant; (blank) Not significant

\subsubsection{Test of significance for project administration expertise}

Table 8 presents the results of the Z-tests of each question in Category 8 (see Appendix A - The Primary Research Instrument), and shows that for two of the eleven skills listed in the Project Administration Expertise category, significantly ( $p$-value $=\alpha<=0.0003<0.001$ ) more than twothirds (or 66.7\%) of the respondents felt they were appropriately skilled. The respondents felt satisfactorily skilled with three of the eleven skills, and they were significant at $\alpha=0.01$. Therefore, there were six project administration expertise skills in which the respondents thought they were most lacking and of these, respondents felt themselves to be seriously lacking in the expertise to apply contract law, (it was significant at $\alpha=0.91$ ). Since the respondents are lacking in six project administration expertise skills, therefore the null hypothesis is rejected for five skills of competencies (where $\mathrm{p}>=85 \%$ - these are skills that were perceived to be highlydeveloped by the participants) and failed to be rejected for the other six skills of competencies (where $\mathrm{p}<=73 \%$ - these are skills that were perceived to be lacking by the participants).

Table 8 Test of significance for project administration expertise

\begin{tabular}{|l|c|c|c|l|}
\hline Project Administration Expertise & $\mathbf{p}$ & $\mathbf{Z}$ & P-value & Significance \\
\hline Expertise to create a project plan & 0.846 & 2.53 & 0.0057 & $* *$ \\
\hline Expertise to set milestones or deadlines & 0.846 & 2.53 & 0.0057 & $* *$ \\
\hline Expertise to manage a budget & 0.731 & 0.73 & 0.2318 & \\
\hline Expertise to set a schedule & 0.885 & 3.47 & 0.0003 & $* * *$ \\
\hline Expertise to manage time & 0.923 & 4.90 & 0.0000 & $* * *$ \\
\hline Expertise to forecast or estimate & 0.731 & 0.73 & 0.2318 & \\
\hline Expertise to keep records or documents & 0.846 & 2.53 & 0.0057 & $* *$ \\
\hline Expertise to set performance metrics & 0.731 & 0.73 & 0.2318 & \\
\hline $\begin{array}{l}\text { Expertise to execute performance } \\
\text { metrics }\end{array}$ & 0.731 & 0.73 & 0.2318 & \\
\hline Expertise to write proposals & 0.731 & 0.73 & 0.2318 & \\
\hline \begin{tabular}{l} 
Expertise to apply contract law \\
\hline
\end{tabular} & 0.538 & 1.31 & 0.9057 & \\
\hline
\end{tabular}

*** Highly significant; ** More Significant; * Significant; (blank) Not significant 


\subsubsection{Test of significance for tools expertise}

Table 9 presents the results of the Z-tests of each question in Category 9 (see Appendix A - The Primary Research Instrument), and indicates that for two of the three skills listed in the project Tools Expertise category, significantly ( $\mathrm{p}$-value $=\alpha<0.001$ ) more than two-thirds (or $66.7 \%$ ) of the respondents felt they were appropriately skilled. There was one expertise in which respondents thought they were most lacking for this category and that is the skill to use financial management tools (it was significant at $\alpha=0.82$ ). Therefore, the null hypothesis is rejected for two of the three skills of competencies (where $p>=89 \%$ - these are skills that were perceived to be highly developed by the participants) and failed to be rejected for the one skill of competencies (where $\mathrm{p}=58 \%$ - this is a skill that was perceived to be lacking by the participants).

Table 9 Test of significance for tools expertise

\begin{tabular}{|l|c|c|c|l|}
\hline Tools expertise & $\mathbf{p}$ & $\mathbf{Z}$ & P-value & Significance \\
\hline I have computer skills & 1.000 & $\mathrm{Nc}$ & & $* * *$ \\
\hline I know and use project management tools & 0.885 & 3.47 & 0.0003 & $* * *$ \\
\hline I know and use financial management tools & 0.577 & -0.93 & 0.8237 & \\
\hline
\end{tabular}

*** Highly significant; ** More Significant; * Significant; (blank) Not significant

In summary, the above tests of significance for the nine categories of skills of competencies reveal the following:

- More than two-thirds (66.7\%) of the respondents felt that they were appropriately skilled (selected 'skilled' or 'highly skilled' as an answer) for all the skills of competencies in the following categories: Analytical Expertise category (Category 4) and Personal Characteristics category (Category 7); and

- Two-thirds $(66.7 \%)$ or more of the respondents were lacking in some of the skills in the following categories: Problem-Solving Expertise category (Category 1), Leadership Expertise category (Category 2), Context Knowledge category (Category 3), People Expertise category (Category 5), Communication Expertise category (Category 6), Project Administration category (Category 8) and Tools Expertise category (Category 9).

Since two-thirds $(66.7 \%)$ of the respondents were found to be lacking some of the skills of competencies in some of the nine categories of skills, therefore the first hypothesis in this study which states that "Project managers in the South African ICT sector perceive themselves to have sufficient project management and leadership skills to manage projects" is rejected. The conclusion, therefore, is that project managers in the South African ICT sector do not have sufficient project management and leadership skills to manage projects.

The tests of significance carried out on the responses given by the respondents to the questions that concern skills of competencies in the nine categories (see Appendix A - The Primary Research Instrument) and subsequent discussions provide an answer to the first research question in this study, which seeks to establish the knowledge base of project managers in the South African ICT sector. The answer is that, out of nine categories of skills of competencies, project managers $(66.7 \%$ or more) lack in some of the skills found in seven categories of skills of competencies. 
It is worth noting that, should the arbitrary value against which the null hypothesis above was tested be $49 \%$ (that is, less than the minimum majority of the respondents), the null hypothesis would have been rejected for each Z-test performed on each skill of competency for all the nine categories of skills of competencies. Therefore, this would have resulted in failure to reject the first hypothesis in this study and thus confirm that the majority of project managers in the South African ICT sector do possess sufficient project management and leadership skills to manage projects.

There could be a number of reasons as to why the respondents are lacking in some skills competencies, as has been revealed above. One of these reasons could be because of the skewed project management training programmes offered by the institutions of higher learning in South Africa (Rwelamila, 2007). Table 10 below matches the findings of this study in this section with those of the study done by Rwelamila (2007).

Table 10 The findings of this study that relate to Rwelamila's (2007) study

\begin{tabular}{|c|c|c|}
\hline $\begin{array}{l}\text { Categories in which } \\
\text { respondents lack some } \\
\text { skills }\end{array}$ & $\begin{array}{l}\text { Corresponding Curriculum } \\
\text { broad topics Rwelamila (2007) }\end{array}$ & $\begin{array}{l}\text { Comments (Match / No match in } \\
\text { the studies) }\end{array}$ \\
\hline Problem-Solving Expertise & Project techniques (PT) & $\begin{array}{l}\text { No match - Rwelamila (2007) } \\
\text { found that the programmes were } \\
\text { strong in this topic. }\end{array}$ \\
\hline Leadership & $\begin{array}{l}\text { Behavioural aspects of project } \\
\text { management (BAPM) }\end{array}$ & $\begin{array}{l}\text { There is a match - Rwelamila } \\
\text { (2007) found that the programmes } \\
\text { were weak in this topic. }\end{array}$ \\
\hline Project Context Knowledge & $\begin{array}{l}\text { Organisational issues / Business } \\
\text { fundamentals. }\end{array}$ & $\begin{array}{l}\text { There is a match - Rwelamila } \\
\text { (2007) found that the programmes } \\
\text { were weak in both topics. }\end{array}$ \\
\hline People expertise & $\begin{array}{l}\text { Behavioural aspects of project } \\
\text { management (BAPM) }\end{array}$ & $\begin{array}{l}\text { There is a match - Rwelamila } \\
\text { (2007) found that the programmes } \\
\text { were weak in this topic. }\end{array}$ \\
\hline Communication Expertise & $\begin{array}{l}\text { Behavioural aspects of project } \\
\text { management (BAPM) / } \\
\text { Controlling techniques (CT) }\end{array}$ & $\begin{array}{l}\text { There is a match - Rwelamila } \\
\text { (2007) found that the programmes } \\
\text { were weak in this topic }\end{array}$ \\
\hline Project Administration & Project techniques (PT) & $\begin{array}{l}\text { No match - Rwelamila ( } 2007) \\
\text { found that the programmes were } \\
\text { strong in this topic. }\end{array}$ \\
\hline Tools Expertise & Project techniques (PT) & $\begin{array}{l}\text { No match - Rwelamila (2007) } \\
\text { found that the programmes were } \\
\text { strong in this topic. }\end{array}$ \\
\hline
\end{tabular}

The next section seeks to analyse the responses of the respondents, which were aimed at establishing whether the organisations of the respondents regard project management as an important discipline. 


\subsection{Perceived Importance of Project Management}

The questions in Section C of the research questionnaire (see Appendix A - The Primary Research Instrument) were aimed at establishing whether the participants' organisations value and regard project management as an important discipline. The participants were then asked to rate their organisations in this regard.

Having now analysed the respondents' answers to questions with regard to perceived importance of project management by organisations of respondents, the second hypothesis of this study needs to be tested. The next section is aimed at testing the second hypothesis in this study.

\subsubsection{Testing of hypothesis 2}

The second hypothesis in this study states that:

"Project management is recognised as an important profession in the South African ICT sector."

This hypothesis was tested using the one sample Z-test for proportions (Diamantopolous and Schlegelmilch, 1997). In the one sample test, it is appropriate to state an arbitrary value against which the hypothesis is tested. For the purpose of this study, the hypothesised proportion that was used was $66.7 \%$, with the idea that we are interested in knowing which specific aspects of project management were well supported by organisations of the participants, as perceived by significantly more than two-thirds in the population. The proportions were calculated by summing up the proportions of respondents who provided "Yes" as an answer to each question of Section $\mathrm{C}$ of the research questionnaire. To establish which specific aspects of project management were well supported by organisations of the participants, as perceived by significantly more than two-thirds in the population, the following hypotheses were formulated:

$\mathrm{H}_{0}$ : The percentage of respondents who chose 'Yes' as an answer is less than or equal to $66.7 \%$; against

$\mathrm{H}_{1}$ : More than $67 \%$ of the respondents chose 'Yes' as an answer.

A test of significance was made to each question of Section $\mathrm{C}$ in the research questionnaire to establish which specific aspects of project management were well supported by organisations of the participants, as perceived by significantly more than two-thirds in the population.

Table 11 presents the results of the Z-tests of each question in Sepction $\mathrm{C}$ of the research questionnaire, and shows that for all five questions, significantly ( $\mathrm{p}$-value $=\alpha<0.001$ ) more than two-thirds (or $66.7 \%$ ) of the respondents perceived their organisations to be fully supportive of all the aspects of project management raised in the five questions. 
Table 11 Test of significance for perceived importance of project management aspects

\begin{tabular}{|l|c|c|l|l|}
\hline $\begin{array}{l}\text { Perceived importance of Project } \\
\text { Management }\end{array}$ & $\mathbf{P}$ & $\mathbf{Z}$ & P-value & Significance \\
\hline $\begin{array}{l}\text { Does your organisation use any project } \\
\text { management methodology? }\end{array}$ & 1.000 & $\mathrm{nc}$ & & $* * *$ \\
\hline $\begin{array}{l}\text { Does your organisation use any project } \\
\text { management tools? }\end{array}$ & 1.000 & $\mathrm{nc}$ & & $* * *$ \\
\hline $\begin{array}{l}\text { Does your organisation support and manage } \\
\text { the distribution of best management practices? }\end{array}$ & 0.923 & 4.90 & 0.0000 & $* * *$ \\
\hline $\begin{array}{l}\text { Does your organisation provide project } \\
\text { managers with career opportunities, training } \\
\text { and mentoring? }\end{array}$ & 0.923 & 4.90 & 0.0000 & $* * *$ \\
\hline $\begin{array}{l}\text { Does your organisation require a project } \\
\text { manager to have any formal training for this } \\
\text { position? }\end{array}$ & 0.885 & 3.47 & 0.0003 & $* * *$ \\
\hline
\end{tabular}

*** Highly significant; ** More Significant; * Significant; (blank) Not significant

Therefore, the null hypothesis is rejected for all of the five questions (where $\mathrm{p}>=89 \%-$ the participants perceived that all aspects of project management that were raised in the five questions as well supported by their organisations).

Since more than $88 \%$ (significantly more than two-thirds) of the respondents confirmed that their organisations supported all aspects of project management that were raised in the five questions (see Appendix A - Section C of The Primary Research Instrument), this therefore provides a compelling reason to accept Hypothesis 2, which states that, "Project management is recognised as an important profession in the South African ICT sector." Accepting Hypothesis 2, therefore, provides an answer to the second research question in this study, which seeks to establish whether project management is recognised as an important profession in the South African ICT Sector.

\subsection{Conclusions and recommendations}

This section presents conclusions and recommendations based on the findings of this study, as they were presented above.

\subsubsection{Demographic Profile of Respondents}

\subsubsection{Conclusions}

- The demographic profile of the respondents shows that the respondents were mostly male $(61.5 \%)$ and white $(53.8 \%)$ respectively. This shows that the project management discipline in the ICT sector in South Africa is still dominated by males and whites.

- The project management experience profile of the respondents indicates that almost half of the respondents $(46.2 \%)$ have relatively little experience $(1-5$ years $)$ in project management, while only $19.2 \%$ of respondents have $11-20$ years of experience in project management. It is therefore clear that that the majority of respondents are less experienced project managers and it further indicates that the majority of projects are managed by project managers who are relatively less experienced in project management.

- The results of this study show that the majority of the respondents $(92.3 \%)$ have received formal training in project management. As it was pointed out earlier on, this is a sign that 
organisations realise the need for providing proper training and support systems for project managers and are therefore moving away from having projects that are managed by 'accidental project managers'.

Based on the above conclusions, the following recommendations have been made.

\subsubsection{Recommendations}

- Organisations should strive to bring about a balance in both gender and racial demographics of their workforce through the use of employment equity policies. Not only are organisations under pressure from South African government policies to bring about a balance in gender and race, but they are under pressure from their employees too. Organisations should look beyond policies that are meant to 'force' them to have a diverse workforce, but should rather see the competitive advantages that are brought about by a diverse workforce.

- Organisations should start looking at initiating coaching and mentorship programmes to provide experience to the majority of their project managers who are relatively less experienced. Such programmes will improve the success rate of ICT projects, as it is reported that $97 \%$ of successful projects have an experienced project manager at the helm (Standish Group, 2004).

The next section discusses some key conclusions on the knowledge base of the respondents and then makes recommendations based on these conclusions.

\subsubsection{Knowledge Base of the Respondents}

This section presents conclusions that are deduced from the findings about the knowledge base of the respondents as they were presented earlier on in this study.

\subsubsection{Conclusions}

The results of this study show that more than $92 \%$ of respondents received formal training in project management. However, some of these respondents still lack some project management skills, as the test results of the hypothesis tests of the first hypothesis in this study revealed.

Earlier on in this study it was mentioned that there are a number of possibilities as to why the respondents lack such skills, and one of the possibilities could be because of the skewed project management training programmes offered by the institutions of higher learning in South Africa (Rwelamila, 2007). To help organisations address the skills competency problem, the recommendations in the next section have been suggested.

\subsubsection{Recommendations}

- Project management training programmes review - Institutions of higher learning and other institutions in South Africa that offer project management training programmes should review their programmes with the aim of bringing in a balance in the technical knowledge base and socio-cultural base content in their programmes, as it was recommended by Rwelamila (2007). Technical skills, project teamwork fundamentals and project management concepts should be integrated into the curriculum of project management programmes.

- Re-training - The respondents should be re-trained in the areas in which they lack skills competencies. Such training should be a focused one which is aimed at addressing the skills lacking and should enable the trainees to be self-sufficient in project management. 
- On-the-job training - The ICT sector is a fast-paced industry and therefore it requires continuous, regular re-training of those who work in it. The other issue that prompts ongoing training on the part of project managers is the complex nature of the projects that managers deal with, as well as the uniqueness of projects in general. It is said that the most effective way to learn how to be a project manager is through on-the-job training (Thornberry, 1987).

- Mentoring and coaching programmes - Some of the respondents might require advanced training in order to improve some of the skills lacking. For example, mentorship and coaching skills are generally not offered as part of a fundamental project management programme, but as part of an advanced project management training programme. Such programmes will ensure that organisations share knowledge, 'grow' their own project leaders who will not only become good project managers but also project managers that fully understand the organisational culture and will perpetuate good project management practices - promoting the same practices and procedures they themselves have been exposed to (Thornberry, 1987).

The next section is aimed at discussing conclusions on the respondents' organisations with regard to their perception of the importance of project management as a discipline. It will also provide recommendations based on the conclusions reached.

\subsubsection{Perceived Importance of Project Management}

This section presents conclusions that have been reached based on the findings of the importance of project management as perceived by the respondents. These findings were presented and discussed in Chapter 6 of this study.

\subsubsection{Conclusions}

The test results of the hypothesis tests of the second hypothesis in this study revealed that more than $88 \%$ of the respondents confirmed that their organisations recognised project management as an important profession in the South African ICT Sector. The conclusion therefore, is that the organisations in the South African ICT Sector recognise project management as an important profession and this is a move in the right direction.

\subsubsection{Recommendations}

The fact that organisations in the South African ICT Sector regard project management as an important profession can be further strengthened by tangible results, such as an increase in the rate of successful projects in the ICT sector. Finally, when South African organisations in the ICT sector implement the above recommendations, that would not only be seen as accepting project management as an important discipline, but it would also be a sign that organisations are interested in improving the success rate of projects in the ICT sector in South Africa.

\section{FURTHER RESEARCH}

This study is confined to ICT organisations listed on the Johannesburg Securities Exchange. Inclusion of more ICT organisations in similar future research studies should provide a more complete picture with regard to the knowledge base of project managers in the South African ICT Sector, as well as the perceived importance of project management as a profession in the South African ICT Sector by organisations in this sector. Furthermore, future research studies could 
look at the relationship between performance levels of projects and the project managers' knowledge base in the South African ICT sector.

\section{REFERENCES}

[1] Anderson, D.K. and Merna, A. 2006. 'Project Management is a Capital Investment Process', Information Systems Management, 23(4): 43-49.

[2] Boyle, T.A. and Strong, S.E. 2004. 'Skill Requirement of ERP Graduates', Journal of Information Systems Education, 17(4): 403-412.

[3] Brill, J.M., Bishop, M. J. \& Walker, A.E. 2006. 'The Competencies and Characteristics Required of Effective Project Manager: A Web-Based Delphi Study', Association for the Educational Communications and Technology, 54(2): 115-140.

[4] Burke, R. 2003. Project Management: Planning \& Control Techniques. 4th ed. South Africa: Burke Publishing.

[5] Carbone, T.A. and Gholston, S. 2004. 'Project Manager Skill Development: A Survey of Programs and Practitioners', Engineering Management Journal, 16(3): 10-16.

[6] Ceran, T. and Dorman, A.A. 2004. 'The Complete Project Manager', Journal of Architectural Engineering, 1(2): 67-71.

[7] Crawford, L. and Pollack, J. 2007. 'How Generic Are Project Management Knowledge and Practice?', Project Managment Journal, 38(1): 87-96.

[8] Dainty, A., Cheng, M. \& Moore, D. 2005. 'A Comparison of the Behavioral Competencies of ClientFocused and Production-Focused Project Managers in the Construction Sector', Project Management Journal, 36(2): 39-48.

[9] Diamantopoulos, A. and Schlegelmilch, B. 1997. Taking the fear out of data analysis: step-by-step approach. UK: Dryden Press.

[10] Day, J. and Bobeva, M. 2003. 'Successful IS project leaders: a situational theory perspective'. Electronic Journal of Information Systems Evaluation, 6(2): 75-86

[11] Dvir, D., Sadeh, A. \& Malach-Pines, A. 2006. 'Projects and Project Managers: The Relationship between Project Managers' Personality, Project Types and Project Success', Project Management Journal, 37(5): 36-48.

[12] Geist, D.B. and Myers, M.E. 2007. 'Pedagogy and Project Management: Should you practice what you preach?', Consortium for Computing Sciences in Colleges, 23(2): 202-208.

[13] Gehring, D.R. 2007. Applying Traits Theory of Leadership to Project Management', Project Management Journal, 38(1): 44-54.

[14] Gillingham, A. 2006. 'Focus on Project Management', Business Day, 6 November: 8.

[15] Graham, R.J. and Englund, R.L. 2004. Creating an Environment for Successful Projets. 2nd ed. USA: Jossey-Bass.

[16] Harrison, F.L. 1987. 'Motivating the Participants'. In: Lock, D. ed. Project Management Handbook. England: Gower Technical Press Limited. 529-560.

[17] Huff, R.A. and Prybutok, V.R. 2008. 'Information Systems Project Management Decision Making: The Influence of Experience and Risk Propensity', Prject Management Journal, 39(2): 34-47.

[18] Kappelman, L.A., McKeeman, R. \& Zhang L. 2007. 'Early Warning Signs of IT Project Failure: The Dominant Dozen', The EDP Audit, Control, and Security Newsletter, XXXV(1): 1-10.

[19] Kim, Y., Hsu, J. \& Stern, M. 2006. 'An Update on the IS/IT Skills Gap', Journal of Information Systems Education, 17(4): 395-402.

[20] Kimmons, R.L. 1989. Project Management: A Reference for Professionals. USA: Marcel Dekker Inc

[21] Leung, H. 2002. 'Organizational factors for successful management of software =development', Journal of Computer Information Systems, XX(X): 26-37.

[22] Mann, J. 2002. 'IT Education's Failure to Deliver Successful Information Systems: Now is the time to address the IT-user Gap', Journal of Information Technology Education, 1(4).

[23] Marken, L. 1998. 'Project Managers', InfoWorld, 20(40): 113. 
[24] McCormick, I. 2006. 'Same planet, different worlds: why projects continue to fail. A generalist review of project management with special reference to electronic research administration', Perspectives, 10(4): 102-108.

[25] Muzio, E., Fisher, D.J., Thomas, E.R. \& Peters, V. 2007. 'Soft Skills Quantification (SSQ) for Project Manager Competencies', Project Management Journal, 38(2): 30-38.

[26] Nelloreisher, R. and Blachandra, R. 2001. 'Factors Influencing Success in Integrated Product Development (IPD) Projects', IEEE Transactions on Engineering Management, 48(2): 164-174.

[27] Neser, J.J., Joubert, S.J., Sonnekus, E.F. 1995. Introduction to methodology: Criminology, penology and policy science. Pretoria. University of South Africa.

[28] Pheng, L.S. and Lee, B.S.K. 1997. 'East meets West: Leadership development for construction project management', Journal of Managerial Psychology, 12(6): 383-400.

[29] Rwelamila, P.M.D. 2007. 'Construction Project Management Education Programmes in South Africa - Addressing the Gap'. In: de Ridder, H.A.J., Wamelink, J.W.F. ed. Second International Conference World of Construction Project Management, Netherlands, August 14, 2007. TU Delft. 1-15.

[30] Schmid, B., and Adams, J. 2008. 'Motivation in Project Management: The Project Manager's Perspective', Project Management Journal, 39(2): 60-71.

[31] Schimmoller, B.K. 2001. 'The changing face of project management', Power Engineering, May: 2830.

[32] Schwalbe, K. 2007. Information Technology Project Management. 5th ed. USA: Thomson Course Technology.

[33] Skulmoski, G.J. 2000. 'Critical Performance Competencies for Cost Engineers', AACE International Transactions, DEV.02: 1-7.

[34] South Africa. The Presidency. 2007. Report on Joint Initiative on Priority Skills Acquisition (JIPSA). Pretoria: The Presidency.

[35] Standing, C., Guilfoyle, A., Lin, C. \& Love, P.E.D. 2006. 'The attribution of success and failure in IT projects', Industrial Management \& Data Systems, 106(8): 1148-1165.

[36] Standish Group. 2004. CHAOS Report. West Yarmouth, MA: The Standish Group.International Inc.

[37] Taylor, J. 2006. A Survival Guide for Project Managers. 2nd ed. USA: AMACOM.

[38] Tesch, D., Kloppenborg, T.J. \& Frolick, M.N. 2007. 'IT Project Risk Factors: The Project Management Professionals Perspective', The Journal of Computer Information Systems, 47(4): 6169.

[39] Thornberry, N.E. 1987. 'Training the Engineer as Project Manager - How to turn technical types into top-notch project managers', Training and Development Journal, 136(10): 60-62.

[40] Tithe, M. 1999. 'Identifying Key Characteristics of Technical Project Leadership', Leadership and Organizational Development Journal, 20(5).

[41] Weirauch, W. 2000. 'What skills do project managers really need?', HP Impact, 79(2): 23.

\section{Authors}

Full name: Mr Robert Hans

Affiliation: None

E-mail address: hansr@tut.ac.za

Full international contact details:

Telephone: +27 (0) 123829721

Fax: +27 (0) 123829203

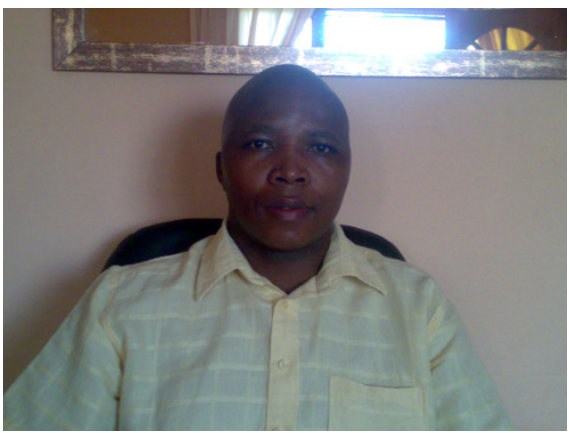


Brief professional biography:

Robert Hans is a lecturer at Tshwane University of Technology (TUT), where he teaches project management as well as systems analysis and design subjects. He has worked for many years in the ICT industry before joining TUT three years ago. Robert has a master's degree in business leadership (MBL) from University of South Africa Graduate School of Business Leadership. He received a distinction for his research paper in his master's degree. He is currently studying for a doctoral degree with University of South Africa.

Full name: Professor PMD Rwelamila

Affiliation: Pr.CPM with SACPCMP; Fellow of the CIOB - UK,

American Association of Cost Engineers (MAACE) and

American Institute of Constructors (MAIC).

E-mail address: rwelapmd@unisa.ac.za

Full international contact details:

Telephone: +27 (0) 116520236

Fax: +27 (0) 116520299

Brief professional biography:

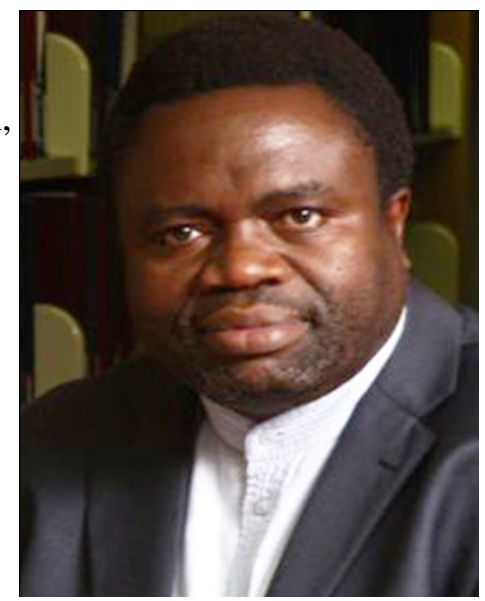

P. D. Rwelamila is a Professor of Project Management at the Graduate School of Business Leadership (GSBL), University of South Africa (UNISA) and President of The South African Council for Project and Construction Management Professions (SACPCMP); Joint coordinator: International Council for Research \& Innovation in Building \& Construction (CIB) - W107: Construction in developing countries; Chairperson and non executive director of MSINGI Construction Project Management (Pty) Ltd based in Cape Town. Professor Rwelamila is a former Vice President (Education) of the Chartered Institute of Building (CIOB) - Southern Africa. Formerly a Senior Partner of Quantum Consultants (Pty) Ltd - a Project Management \& Quantity Surveying consulting firm in Botswana. He graduated in Construction Economics and project management. He has a Masters Degree in Construction Management from Brunel University and a Ph.D. in Project Management and Procurement systems from the University of Cape Town. He has worked in a number of countries, including Tanzania, Kenya, Uganda, Botswana, Zambia, Australia, United Kingdom and Sweden. He has more than 190 published and peer-reviewed journal papers, chapters in books and conference proceedings. 